\title{
Perceived Challenges of Academic Staff Production of Research Papers in Colleges of Education in Ghana
}

\author{
I. Amoako, E. O. Boahen, A. Abaidoo, and S. Oti-Boateng
}

\begin{abstract}
Apart from improving the ranking of the individual and his/her institution, research publications are also known to make important contributions to the advancement of knowledge and formulation of government policies, thus enhancing institutional, sector and/or national and global development. The study explored challenges that College of Education tutors face in line with publishing research papers and other scholarly materials. Utilizing concurrent nested mixed method design, tutors of all Colleges of Education institutions in Ghana were targeted, however, 190 tutors were drawn from the five Colleges of Education zones in Ghana to participate in the study. A checklist of $\mathbf{7 2}$ internal consistency reliability was used to gather the quantitative data while interview schedule was used to gather qualitative data about challenges that affect academic staff publishing of research products. Data to answer research question one was analyzed using descriptive statistics, specifically, percentages and frequencies. However, data to answer research question two were analyzed using Braun and Clarke thematic analysis approach. Findings revealed that college tutors used in the study had awareness and knowledge about how research articles and abstracts are produced but not for other research products such as monograph, book chapters and so on. The study findings further showed that, weaker foundational knowledge and skills in research methodology, lack of writing experience, deficient information technology skills and lack of mentorship constituted the challenges that affected frequent publishing of research products among college tutors. Regular workshops of research methodology and production of research papers should be organized for college tutors by college management. The study further recommends that the Ministry of Education in collaboration with Ghana Education Trust Fund (GetFund) as a matter of priority should work on improving and building more infrastructure, specifically, offices for academic staff and technological infrastructure to enhance more research-based activities within the Colleges.
\end{abstract}

Index Terms - academic staff, challenges, job load, professional promotion, scholarly papers.

\section{INTRODUCTION}

Research is essentially the search for information in the furtherance of knowledge. It involves the compiling, organizing and analysis of information to improve the human understanding of phenomena under study [1]. In recent times, globalization has created intense interest in research for universities and delivery of quality education in the world [2]. Research plays crucial role in the development of nations across the globe. Hardly could any country advances without 'empirical studies' directing the path of such development,

Published on June 21, 2021

I. Amoako, Atebubu College of Education, Ghana.

(corresponding e-mail: mightymankojo@yahoo.com)

O. E. Boahen, Atebubu College of Education, Ghana.

(e-mail: opokuboahenedward@gmail.com) and this explains why advanced countries consciously spend adequate resources on research activities to bring desire quality of lives to their citizens [3]. Research if wellstructured in a country could bring crucial change in society and make lives more pleasant by bringing in desired development [3]. If research, teaching, and community engagement fade away, knowledge production for the country would be adversely affected. It is therefore the responsibility of academic institutions (e.g., Colleges of Education $[\mathrm{CoE}]$ institutions and Universities etc) to work harder to fulfil the mandate of knowledge production. Crammer [4] for example asserts that productivity of an academic institution (i.e., tertiary institution) can be measured by research and publications. Still emphasizing on the relevance of publication to an academic institution, Shumba [5] stated that the quality of an academic institution is measured by its research output. In an agreement with earlier studies, Miller et al. [6] equally postulated that journal articles publication is an important indicator of research productivity for academics and academic institutions. Similarly, Kapp et al. [7] also sees publishing of research works as being a key indicator of academic quality and worth. Clearly, it is therefore evident in the literature that apart from improving the ranking of the institution, research publications are also known to make important contributions to the growth and development of industries and formulation of government policies, thus enhancing national and global development.

On the part of scholars in tertiary institutions, writing for the sole purpose of publishing is an outstanding privilege that enhances one's skill of innovative ways of thinking [8]. Publishing of research manuscripts, also provides the academician an opportunity to share original ideas and thoughts, take a role, and report the findings properly based on foundational knowledge in a particular area [9]. Moreover, academicians strive to publish their research ideas, thoughts, and innovations in quality journals to influence societal change and make positive contributions in their fields of endeavour [10].

One of the core missions of academic institutions is to advance, create and disseminate knowledge through research and provide service to the community. These publication of research materials form the major basis for decision-making among appointment and promotion committees. Apart from this, researchers are driven by the need for self-actualization and continuous desire to have their research works

A. Abaidoo, Bia Lamplighter College of Education, Ghana (e-mail: abaidoo.angelina736@ gmail.com). 
recognized within the scientific community as the reasons for publishing [10]. In addition to these inherent and professional benefits of publishing, scholarly manuscript publications may in real terms yield monetary rewards to researchers as they may use highly ranked publications to apply for research grants and travel funding [11], [12]. Increasingly, academic funding and staff development decisions are often based on the number of papers and perceived quality of such academic papers [13]. The role of scholarly publications can sometimes be far-fetched. For instance, the research output of a particular academician may be the singular basis for taking redundancy decisions. The end results of such decisions is what some scholars refers to as "you publish or you perish phenomenon" [14], [15].

Despite the fact that many academicians recognize the importance of publishing and a number of them often manage to publish their research manuscripts, the choice of writing and publishing in highly acceptable journal is not always a decision they consider to be simple and easy. Studies have shown that enormous challenges confront academicians when it comes to writing and publishing of research papers. For example, Okoduwa et al. [16] conducted a study to ascertain the attitudes, perceptions, and barriers to research and publishing among academics and reported that lack of writing experience, funding, professional mentorship, and high publication fees constituted the challenges that inhibit frequent production of academic papers. On the same issue but in a different empirical study, [3] also discovered that family problems, financial constraints, inadequate information accessibility, inadequate information literacy and inadequate incentives from employers were the major factors hindering research productivity among academic staff. The above challenges are believed to be the bane of most workrelated problems for an academician. For instance, an academician 'perishing' because he/she is not publishing could be denied of promotion and other grants, hence, for academicians to progress through their career, the rule of publish or perish is more sensitive and critical [17].

In the early 2000s, following a comprehensive review of the educational system in Ghana, the Government published a White Paper and declared all 'Teacher Training Colleges' (now Colleges of Education) to be upgraded into diplomaawarding institutions status and be affiliated to the education oriented traditional university at that time, that is, University of Cape Coast [18]. The passage of the Colleges of Education Act in 2012, Act 847, further helped concretize the new status of the College of Education institutions as tertiary institutions directly placed under National Council for Tertiary Education (NCTE), now Ghana Tertiary Education Commission (GTEC) which is government agency responsible for the regulation of tertiary education institutions in Ghana. With the already mentioned legal framework in place, Colleges of Education institutions were upgraded to the status of tertiary institutions, hence, all conditions of service and practices such as production of research papers were to be done by academic staff within the Colleges as in the case of academic staff within the traditional universities.

Pursuant to the dictate of the Harmonised Conditions of Service (HCS) for CoE as well as the Harmonised Scheme of Service (HSS) for CoE documents, teaching staff of Colleges are expected to write and publish papers in peer-reviewed journals to contribute to the advancement of knowledge and for professional upgrade (HCS, p. 54; HSS, p.7). An anecdotal information gathered as an initial step to the conduct of this study by all the authors of this paper suggest that academic staff of Colleges of Education institutions in Ghana are publishing but at a limited quantity and a slow pace as compared to their counterpart teaching staff at the traditional Universities. A curious mind may ask, what are the prevailing challenges that account for academic staff of College of Education tutors in Ghana not publishing as expected? Answers to the foregoing question are not readily available because available studies in Ghana have shown that researchers attention have not being on the issue of why College tutors in Ghana are not publishing but rather on issues such as factors that influence researchers' journal selection decisions [10], ways of promoting local publishing and authorship [19], revolution in the book publishing industry [20] as well as scholarly communication methods of Universities in Ghana [21]. Until now, there appears to be paucity of information regarding challenges that academic staff of College of Education institutions in Ghana face that tend to inhibit frequent development and publishing of academic manuscript. This present study therefore sought to explore the possible challenges that academic staff encounter relative to writing and publishing of papers in scholarly journals. In the context of this study, published papers as a phenomenon of interest is in reference to book chapters, technical report, monograph, journal articles (usually articles published in "peer-reviewed" journals), papers in conference proceedings as well as conference abstracts.

According to Magolda [22] research is a science of constructive development in which academics engage in, and direct knowledge construction process in their disciplines, impact that process to learners and give learners (i.e., novice researchers) opportunities to practice and become astute future researchers. It is obvious that academic institutions have the core responsibility to extend industrial or commercial application of their research findings to advance the frontiers of knowledge and generating quality human resources. Academic institutions are therefore expected to convey their missions in line with the role that faculty's involvement in research activities and publishing can be taken as index of institutional status [22]. An increase in research publication has become a guarantee for prestige and an important factor for institutional ranking [23]. An academic institution's annual research production is not only used as a benchmark for lecturer's promotion but also basis for lifting institution's reputation and ranking.

It is generally acknowledged in the literature that academic institutions in Sub-Saharan Africa have weak research and innovation capacities due to various challenges they encounter [23]. In discussing some of the challenges, Tierney [23] highlighted, inadequate research skills among teaching staff, deficit facilities or infrastructure and inadequate funding for institutions and individuals to carry out research. In corroborating what Tierney [23] discovered, in a qualitative study, Kumwenda [24] pointed out that, in African institutions, some academics lack mentorship to make them proficient and prolific writers. Many of the extant studies e.g., Bland et al. [25]; Shin \& Cumming, [26] have categorized factors influencing research engagement and productivity 
into two main groups: personal/individual and institutional/environmental. Personal/individual factors may include age, gender, academic rank, motivation, research knowledge and skills, research orientation, and collaboration. Institutional/environmental factors are an umbrella term that can refer to institutional missions, sizes, orientation, leadership, availability of resources, rewards, mentoring programs, and institutional research policy and culture. The person-environment and/or individual-institutional dichotomy has been widely employed as a framework to investigate factors influencing academics' research productivity [26]-[28]. However, there seems to be a relatively limited number of research studies in Ghana relating to challenges that academic staff face in Colleges of Education institutions regarding production of research materials. In investigating the foregoing, questions to be addressed included:

(1) What kinds of scholarly product(s) do academic staff of Colleges of Education institutions in Ghana have adequate knowledge about?

(2) What individual and/or institutional factors serve as challenges for research paper production among Colleges of Education tutors in Ghana?

\section{Methodology}

\section{A. Design}

The prime purpose of the study was to investigate perceived challenges of academic staff in the production of research papers within the Colleges of Education $(\mathrm{CoE})$ institutions in Ghana. In the quest to achieve the foregoing purpose, two forms of data (i.e., quantitative and qualitative) were taken from respondents at one data collection phase to address different research question. This approach therefore necessitated the use of concurrent embedded (nested) mixed method design [29]. The quantitative data provided answers for research question one whereas the qualitative data provided answers for research question two.

\section{B. Participants}

Colleges of Educations institutions are spread abroad the length and breadth of Ghana. In all, the Colleges are classified into five zones, that is, Ashanti-Brong Ahafo zone, Volta zone, Central-Western zone, Northern zone and EasternAccra zone. Using simple random selection approach (specifically, random numbers method), a single College (names withheld for ethical reasons because of the sensitive nature of the study) was selected from each of the five zones of Colleges of Education in Ghana. In all, five Colleges were included in the study where a disproportionate quota sampling method was utilized to pick thirty-six (36) participants from each selected College within a zone leading to a total of 180 participants from the five zones. For the purposes of the interview sessions as part of the study, education departmental heads and a tutor from each chosen College was sampled to be interviewed. In all, 190 participants (i.e., 180 for survey and 10 for interview sessions) were recruited for the study.

\section{Measures}

Two instruments were developed and validated for the purpose of this study. The first instrument was a six-item checklist that measured the kinds of research productivity that academic staff of the selected Colleges frequently engage in. The checklist had an internal consistency of .72. The second instrument was an interview schedule that measured participants' views about challenges that academic staff face relative to their research productivity mandate. The two instruments were pilot tested to fine-tune the items.

\section{Data Collection and Analysis Plan}

Formal permissions were sought from gatekeepers within the selected Colleges of Education campuses. As ethics in research demands, participants were made to sign consent form and they were as well assured of confidentiality and anonymity. After exhausting all ethical protocols, the researchers used eight weeks to administer the checklist to the participants at their respective campuses. The interview sessions were also organized alongside with the collections of the quantitative data. After the data collection and management, data to answer research question one was analyzed using descriptive statistics, specifically, percentages and frequencies. However, data to answer research question two were analyzed using Braun and Clarke [30] thematic analysis approach.

\section{RESULTS}

Research Question One: What kind(s) of scholarly product(s) do academic staff of Colleges of Education institutions in Ghana have knowledge about?

The research question sought to investigate scholarly materials that $\mathrm{CoE}$ tutors have awareness or knowledge about. Respondents' responses were measured with a quantitative checklist and summary of the findings are shown in Table I:

TABLE I: SCHOLARLY MATERIAL(S) OFTEN PRODUCED BY TUTORS

\begin{tabular}{|c|c|c|c|c|c|c|c|}
\hline \multirow[t]{2}{*}{$\begin{array}{l}\text { Research } \\
\text { Products }\end{array}$} & \multicolumn{2}{|c|}{$\begin{array}{c}\text { Have } \\
\text { adequate } \\
\text { knowledge } \\
\text { about and can } \\
\text { produce }\end{array}$} & \multicolumn{2}{|c|}{$\begin{array}{c}\text { Have less } \\
\text { knowledge } \\
\text { about and } \\
\text { may not be } \\
\text { able to } \\
\text { produce }\end{array}$} & \multicolumn{2}{|c|}{$\begin{array}{l}\text { Have no } \\
\text { knowledge } \\
\text { about and } \\
\text { cannot } \\
\text { produce }\end{array}$} & \multirow[t]{2}{*}{$\begin{array}{l}\text { Total } \\
\text { number } \\
\text { of } \\
\text { tutors }\end{array}$} \\
\hline & No & $\%$ & No & $\%$ & No & $\%$ & \\
\hline $\begin{array}{l}\text { Articles in } \\
\text { Refereed } \\
\text { Journals }\end{array}$ & 120 & 67 & 40 & 22 & 20 & 11 & 180 \\
\hline Book Chapters & 15 & 8 & 90 & 50 & 75 & 42 & 180 \\
\hline $\begin{array}{l}\text { Scholarly } \\
\text { Books }\end{array}$ & 30 & 17 & 50 & 28 & 100 & 56 & 180 \\
\hline $\begin{array}{l}\text { Technical } \\
\text { Reports }\end{array}$ & 10 & 6 & 65 & 36 & 105 & 58 & 180 \\
\hline Monograph & 5 & 3 & 40 & 22 & 135 & 75 & 180 \\
\hline $\begin{array}{l}\text { Abstract for } \\
\text { Conferences }\end{array}$ & 150 & 83 & 10 & 6 & 20 & 11 & 180 \\
\hline
\end{tabular}

Source: Field Data, 2021.

From Table I, results show that majority $(n=120,67 \%)$ of the respondents had adequate knowledge on refereed journal articles, which further, indicate that their knowledge level is enough to assist them to produce same. Again, majority $(n=150,83 \%)$ of the respondents also agreed that they had substantial amount of knowledge on 'Abstract writing' such 
that they could even produce same for a conference. Aside respondents reporting of having knowledge on articles and abstract writing, they indicated that for other academic documents such as Book Chapters, Technical Reports, Monograph and so on, they had no knowledge about how such documents are being produced. For purposes of emphasis, majority $(n=75,42 \%)$ of the respondents reported that they had no knowledge about the production of Book Chapters for publication. A greater number $(n=105,58 \%)$ also indicated that they had no knowledge about how to produce a Technical Report for publication purposes. Further, majority $(n=135,75 \%)$ of the respondents professed that coming up with a Monograph is not something they know how to do. All in all, the data appears to suggest that tutors of the sampled colleges had adequate knowledge on what a Research Article and Abstract is all about and may even be able to produce some. However, when documents such as Book Chapters, Scholarly Books, Technical Reports and Monograph are mentioned, they had no clue about how to produce such materials.

Research Question Two: What individual or/and institutional factors serve as challenges for research materials production among Colleges of Education tutors in Ghana?

The research question aimed at eliciting responses from tutors regarding individual and/or institutional challenges that affect the production of scholarly materials. Scholarly materials in this context were in reference to research papers, monograph, technical report, scholarly text books and so on.

In order to comprehensively organize respondents' subjective responses on the issue of problems hindering research manuscript production, two themes were identified. That is, individual factors and institutional factors. Responses have been arranged along the lines of the identified themes. In all, nine out of ten respondents chosen expressed their views in a face to face interview sessions on what they feel are individual and institutional factors that hinder frequent publishing of research papers as expected of them as scholars. The following transcriptions represent what transpired on the first theme:

\section{A. Individual Factors that Hinder Tutors from Publishing Research Products}

When the question of; what are some of the individual factors that affect the rate at which you publish research manuscript? For this question, respondent $\mathrm{A}$ had this to say:

"Well, for me I wish I have enough time to sit down to write research papers. The issue is, I serve on several committees in my college, so I do not get the time that I deserve to sit down and write, and this has worked against me (Respondent A, 45yrs)".

When a follow-up question was posed at the same respondent, that is 'do you think time is the only factor that hinders your frequent writing?' She further answered:

"yes, I have no other personal problems, my only problem is that I do not get time".

For the second respondent, he had this to say on the same question:
"Colleague, for me my major challenge is ICT, I have knowledge in research, but I am not skilled in the use of information technology, so I always suffer when I attempt to write" ......again, because I am not good at IT, searching for information online is really a problem for me (Respondent B, 40yrs)".

The same question that was asked respondent $\mathrm{A}$ and $\mathrm{B}$ was also posed at respondent $\mathrm{C}$, for him, this is what he said:

"You see; let me tell you, this publication thing is difficult oooo. Even the fact that you need to read other peoples work is not easy. The whole thing is difficult for me ......it is not easy for us, but we shall overcome (Respondent C, 38yrs)".

When he was asked to be specific on which aspect of the writing of papers, he finds challenging, he later said:

"Using the computer to search for and download research materials is so difficult for me because I am not too good when it comes to the use of the computer and Microsoft word".

Respondent 4 also responded to the same question as stated above by saying that:

"It is actually high time since I finished my masters and at first, that is, when the status of colleges was not tertiary, we were not publishing so it has become so difficult to do so now. I do not have writing experience and also, I do not get people who are good to partner with me to write something and so it is really a problem for me".

Amazingly, respondent 4 seems to be pointing fingers to the direction of technical knowhow of research activity. As others were lamenting on Information Technology and gadget usage in research production, he had something different to say.

"My friend the way we were taught research in our universities did not help some of us. For me I am not dull, I am very good, but I did not get the right exposure that is why I am not able to publish. And here too, I have tried to get people to partner them, so we publish but everyone seems to be busy of some kind (Respondent D, 42yrs)".

As indicated by the fourth respondent, the fifth respondent also lamented on her lack of skill in research product development. She responded this way:

"Ya!, for me, I do not know how to do all that you are mentioning. Yes, I know they exist, and I also know that by policy we are to publish but the truth is that I do not know how to do it and I have also not received any mentorship in that line so what should I do? I will only teach my courses and when my retirement time is due, I leave for the young ones to continue (Respondent E, 51yrs)".

Another respondent said that: 
"OOOh for me, I have not bought the required materials that will aid my publishing. I have plans to buy laptop, modems and pen drive and let some of my colleagues to assist me learn how to use them so that I can publish because I do not have writing experience. Again, one thing which is also a problem for me is time.....you know, research is about time, I am too busy in this school because of administrative duties. In fact, time to go to the field to take data would also be a problem (Respondent F, 32yrs)".

On the first theme, the study explored individual challenges that hinder tutors from producing research materials such as journal articles, conference manuscript, scholarly textbooks, technical reports and so on. Generally, the study discovered that lack of writing experience was a problem for some of the tutors. In the face-to-face interview, some of the respondents indicated that they have not had the opportunity to be coached by experience colleagues on how to write research papers and so it has become a difficult task for them to do so. Another issue raised was the lack of information technology skills among some tutors. The use of desk top computers, laptops, electronic tablet, WiFi systems and even Microsoft word were found to be herculean task for some of the tutors. Once the search for, as well as the organization of scholarly information are premised on a person's proficiency in the usage of the foregoing ICT tools, one may experience problems in publishing. Moreover, inadequate time at the disposal of some tutors due to teaching loads were also noted to be part of the problems. Finally, some of the respondents' professed to be weak in research methodology. Foundational knowledge in research methodology is key to frequent development of research papers, however, respondents gave a contrary view. The weaker foundational knowledge in research among some of the tutors is likely to have been emanated from their highest qualification or research experience in the university. For example, if a tutor, read a non-thesis master programme (e.g. Master of Education [M.Ed], Master of Arts [M. A] etc.), he or she is more likely to experience difficulty in the production of research products.

\section{B. Institutional Factors that Hinders' Tutors from Publishing Research Product(S)}

As part of the interview sessions, the researcher also asked respondents to report on some of the institutional factors that has blocked their chances of publishing frequently as expected. The data was collected using an interview schedule and the following responses were gathered and transcribed: Respondent ' $A$ ' had this to say on institutional challenges:

"It is so difficult to publish in this college. I am saying so because we have poor internet systems in this college.... if you like try our WiFi here and see. So, if you do not really have time can you use this poor network to publish? (Respondent A, 45yrs)".

The researcher posed the same question to the rest of the respondents and had series of answers as follows:

"[Name withheld] college is really not supporting us to publish at all, you see, aside the fact that the school has no offices for teaching staff, the school has no proper technological infrastructure such as WIFI system, wellresourced ICT lab to help us get the right information for publication (Respondent B, 40yrs)".

This is what the third respondent also had to say:

"Sir, let me ask you, how do you expect tutors to publish in a school that people have no mentors unlike the traditional universities that new lecturers are assigned to senior lecturers and professors for mentorship. Here, throughout the year there will be no proper workshop on how to write research papers and how to attend conferences yet they expect me to know...hmmmm...it is really a problem (Respondent C, 38yrs)".

He further hinted that the college within which he finds himself does not have good network system to edge tutor on to publish as expected.

"Could you imagine that in this school we do not have a working internet system. It appears no one cares, complains and further complains have been made yet we are still not seeing any change".

Aside the technological infrastructure another respondent also had this to say:

"My brother some of us, the administrative duties on us are too much. What is worrying is that those administrative duties do not really count in our promotion as much as the publications. The school leadership is also not making any effort to get extra research grant for tutors to use to produce more (Respondent D, 42yrs)".

In what appears to be a list of challenges, the fifth respondent mentioned the following:

"We have poor internet system, we do not have our own offices, lack of unity among college tutors which may lead to publication are completely missing of workshops on how to write research paper (Respondent F, 32).

In all, respondents were of the view that in their colleges they had poor technological infrastructure. This is to say that, for some of the tutors, access to desk top computers and consistent internet is an institutional problem that they face. Aside, the technological infrastructure issue, some of the tutors lamented that their institution has allocated to them much of administrative duties which has crippled them from publishing. For some tutors, grants for the research activities were not coming forth from their institutional managers and they are only left to manage the inadequate book and research allowance provided by government. In an attempt to justify the assertion of 'government book and research allowance not being inadequate for research activities within a year', respondents indicated that, they spend more of the government grant on books than on production of research materials because books are costly in recent times. Finally, lack of mentorship and collaboration among tutors and inadequate offices for individual tutors also constituted some 
of the institutional factors that inhibited their frequent production of research products.

\section{DISCUSSION}

The first research question sought to investigate research product(s) that Colleges of Education tutors have adequate knowledge on. Findings showed that respondents had adequate knowledge on how to craft research articles and abstract for conferences. However, for other scholarly documents such as book chapters, monograph, technical reports etc., they reported that they had insufficient knowledge and may not be able to produce them. Academic staff have a responsibility to contribute to the scientific community by publishing empirical works to sustain and advance knowledge. The finding corroborates with the studies of Stock [31] and Peat et al. [32] who discovered that academic staff of tertiary institutions have awareness and knowledge on how to produce research papers. The idea that academic staff of CoE have knowledge about articles and abstracts are so important since those documents are the primary documents that dominates knowledge generation within the scientific community. Other empirical studies in the literature are supported by the current position of this paper in that for example, in the literature, Kapp et al. [7] had earlier reported that publishing of articles really contribute to the development of industries and formulation of government policies, thus enhancing national and global development. Again, awareness and knowledge of how to write research articles is important because it equip academic staff with innovative ways of thinking which subsequently affect how they unpack subject content into learners [8]. Further, knowledge of writing of abstract for conferences and articles may also provide opportunities for grants and travel funding [11], [12], which has the benefit of providing exposure to academic staff beyond their research locale.

Having awareness and knowledge of academic products such as research articles and conference abstract does not in itself suggest that one is publishing them. Personal experience by the researchers as college tutors portrayed existences of challenges which needed to be empirically examined. Based on the foregoing assumption and personal experience, the study had an objective to explore individual and institutional challenges that affect academic staff of Colleges of Education institutions in Ghana in the production of research products. Findings revealed lack of writing experience, inadequate time due to burdensome teaching load, poor information technology skills, weaker foundational knowledge for the production of some research product such as scholarly book chapters and so on. Again, lack of mentors constituted individual challenges that hinder academic staff from frequently publishing research product such as articles, monograph, book chapters and so on as required. For institutional factors that affect research production, respondents mentioned poor technological infrastructure, lack of offices, inadequate grants for the research activities, lack of mentorship and collaboration among tutors as the issues of concern. The findings in this current study support earlier studies findings in the literature on the outlined challenges. For instance, Okoduwa et al. [16] conducted a study to ascertain the barriers to research and publishing among academics and concluded that lack of writing experience, lack of funding, lack of professional mentorship constituted the challenges that inhibit frequent production of academic papers. Knowledge of information communication technology (ICT) has also been found as a major impediment to the production of research products. In a situation where academic staff are not proficient in the use of computer, tablet and so on, people are more likely not to have interest in reading and searching of scholarly information. As found in this current study, previous studies have also highlighted inadequate research skills among teaching staff, deficit facilities or infrastructure and inadequate funding for institutions and individuals to carry out research [23], [26]. Foundational knowledge in research methodology and availability of resources are crucial in the development of research papers and the lack of any undoubtedly may pose a problem for an individual. Finally, the absence of professional mentorship among respondents as a challenge for production of research papers in this study also appears to confirm many extant studies in the literature [27], [11].

\section{CONCLUSIONS}

Based on the findings of the study Colleges of Education tutors (respondents) may not be utilizing a lot of research products such as monograph, book chapters, technical reports and so on to support teaching and learning since their knowledge and awareness is limited to journal articles and conference abstracts. Further, it can also be concluded that development of research product(s) for publication is likely to be a herculean task for most of the Colleges of Education tutors in Ghana (especially, institutions from which respondents were taken), because of the individual and institutional challenges that they encounter. Institutional and personal challenges may have implication not only for the teaching and learning of courses but also professional development and advancement of tutors. Since publishing of manuscripts enhance lecturers'/tutors' innovative skills of searching and unpacking of contents that are novel and problem solving oriented.

\section{RECOMMENDATIONS}

Based on the findings of the study, it is recommended that:

Management of College of Education institutions in Ghana, (especially, those that served as centers for this present study) should as a matter of policy organize workshop at least twice every semester for tutors to broaden their knowledge and experience in other scholarly research products other than articles and abstracts.

Again, as a matter of policy, Ghana Tertiary Education Commission (GTEC) in collaboration with Principals of Colleges of Education Conference (PRINCOF) and College of Education Teachers Association Ghana (CETAG) should allocate tutors of various Colleges of Education to their affiliated traditional Universities teachers for professional mentorship in the area of academic writing and publishing.

Ministry of Education in collaboration with Ghana Education Trust Fund (GetFund) as a matter of priority 
should work on improving and building more infrastructure, specifically, offices for academic staff and technological infrastructure to enhance more research based activities within the Colleges. This will help speed up the transition pace of the Colleges becoming fully fleshed autonomous universities.

\section{REFERENCES}

[1] Derntl (2014). Basics of research paper writing and publishing. International. Journal of Technology Enhanced Learning, vol. 6, no. 2, p. $105-123$.

[2] Mushemeza, E, D. (2016). Opportunities and challenges of academic staff in higher education in Africa. International Journal of Higher Education, vol. 5, no. 3, p. 236-246.

[3] Simisaye, A. O. (2019). A study of research productivity of the academic staff in research institutes in South-West Nigeria. Samaru Journal of Information Studies, vol. 19, no. 2, p. 75-99.

[4] Cramer, M. M. (2013). Food plant sanitation: Design, maintenance, and good manufacturing practices. United Kingdom, CRC Press.

[5] Shumba, A (2010). Accredited research output by academic staff according to DEHET Benchmarks. Paper presented at a research orientation seminar school of teacher education central. University of Technology, Bloemfontein, South Africa, 18 March 2010.

[6] Miller A.N. et al (2011). Publish or perish: Academic life as management faculty lives it. Career Development International, vol.16, no. 5, p. $422-445$.

[7] Kapp, C.A et al (2011). Writing for publication: An international to overcome barriers to scholarly writing. South Africa Journal of Higher Education, vol. 25, no. 24, p. 741759.

[8] Buttery, T. J. (2010). Writing for professional publication: Three road signs for writing success. Strate Journal, vol. 19, no. 2, p. 1-6.

[9] Klein, J. F. (2008). Advancing one's understanding of school counseling through publication: The "what" and "how" of writing article. GSCA Journal, vol. 1, no. 1, p. 10-11.

[10] Agyei, K. O. K., \& Owusu-Ansah, C. M. (2016). Publishing preferences among academic researchers: Implications for academic quality and innovation. Unpublished master thesis, University of Nebraska - Lincoln.

[11] Wagner, B, A. (2012). Publishing in international journals. European Business Review, vol. 24, no. 1, p. 20-27.

[12] Be'dard, J. and Gendron, Y. (2003). Qualitative research on accounting: Some thoughts on what occurs behind the scene, in Humphrey, C. and Lee, B.H.K. (ed.), The real life guide to accounting research: A behind-the-scenes view of using qualitative research methods. Elsevier, Amsterdam, 192-206.

[13] Villiers, C. \& Dumay, J. (2013). Construction of research articles in the leading interdisciplinary accounting journals. Accounting, Auditing \& Accountability Journal, vol. 26, no. 6, p. 876-910.

[14] Harzing, A. W. (2010). The publish or perish book. Melbourne, Australia: Research Pty Limited.

[15] Englebrecht, T.D., Hanke, S.A. and Kuang, Y. (2008). An assessment of patterns of co-authorship for academic accountants within premier journals: Evidence from 1979-2004. Advances In Accounting, vol. 24, no. 2 , p. $172-181$

[16] Okoduwa, S. I. et al., (2018). Attitudes, perceptions and barriers to research and publishing among. doi: https://doi.org/10.1101/347112.

[17] Moosa A. I (2018) Publish or Perish: Origin and perceived benefits of social and political science doi.org/1024337/9781786434937.

[18] Government of Ghana (2004). White paper on the report of the education reform review committee. Accra: Ministry of Education, Youth and Sports.

[19] Buckle, C. E. (2017). The publishing industry in Ghana: Ways to promote local authors and writing. Unpublished doctoral dissertation, Ashesi University College.

[20] Ry-Kottoh, L. A. (2017). Digital publishing in Ghana: A focus on children's ebooks. Unpublished doctoral thesis, University of Stirling.

[21] Asamoah-Hassan, H. (2010). Alternative scholarly communication: Management issues in a Ghanaian university. Library Management.

[22] Magolda, M. B. (2010). Creating contexts for learning and selfauthorship. Nashville, Tennessee: Vanderbilt University Press.

[23] Tierney, W. G. (2012). The responsive university: Restructuring for high performance. Baltimore, MD: Johns Hopkins University Press.

[24] Kumwenda, S. (2015). Challenges facing young African scientists in their research careers: A qualitative exploratory study. Zomba, Malawi: Chancellor College.
[25] Bland, C. J., Weber-Main, A. M., Lund, S. M., \& Finstad, D. A. (2005). The research productive departments: Strategies from departments that excel. New York: Anker Publishing Company.

[26] Shin, J. C., \& Cummings, W. K. (2010). Multi-level analysis of academic publishing across discipline: Research performance, collaboration, and time on research. Scientometrics, vol. 85, no. 2, p. $582-594$

[27] Jung, J. (2012). Faculty research productivity in Hong Kong across academic discipline. Higher Education Studies, vol. 2, no. 4, p. 1-13.

[28] Angaiz, D. (2015). An investigation of teachers' education faculty research productivity in public sector universities of Pakistan. Unpublished doctoral dissertation, Dowling College, New York, USA

[29] Creswell, J. W., Klassen, A. C., Plano Clark, V. L., \& Smith, K. C. (2011). Best practices for mixed methods research in the health sciences. National Institutes of Health, vol. 2, no. 2, p. 541-545.

[30] Braun, V., \& Clarke, V. (2006). Using thematic analysis in psychology. Qualitative research in psychology, vol. 3, no. 2, p. 77 101.

[31] Stock, W.G. (2000). Was ist eine publikation? Zum problem der einheitenbildung in der wissenschaftsforschung. In Fuchs-Kittowski, K. Laitko, H., Parthey, H. \& UmstÃatter, W. (Eds), Wissenschaftsforschung Jahrbuch 1998, (pp. 53-71). Berlin, Germani: Verlag Publikation.

[32] Peat, J., Elliott, E., Baur, L. and Keena, V. (2002). Scientific writing. Easy when you know how. London: BMJ Books. 